\title{
Economic Analysis of Tomato Production in Cumilla and Rangpur Districts of Bangladesh
}

\author{
Mosammod Mahamuda Parvin ${ }^{1}$, Md. Mizanur Rahman Sarker ${ }^{2}$ \\ ${ }^{1}$ Department of Management \& Finance, Faculty of Agribusiness Management, (SAU), Dhaka, Bangladesh \\ ${ }^{2}$ Department of Agricultural Statistics, Faculty of Agribusiness Management, (SAU), Dhaka, Bangladesh
}

Email address:

mahamudaparvin@gmail.com (M. M. Parvin)

\section{To cite this article:}

Mosammod Mahamuda Parvin, Md. Mizanur Rahman Sarker. Economic Analysis of Tomato Production in Cumilla and Rangpur Districts of Bangladesh. International Journal of Agricultural Economics. Vol. 6, No. 4, 2021, pp. 193-197. doi: 10.11648/j.ijae.20210604.16

Received: July 8, 2021; Accepted: July 27, 2021; Published: August 4, 2021

\begin{abstract}
This paper attempts to analyze the costs, revenues and production problems of tomato in two districts namely Cumilla and Rangpur in Bangladesh. It is necessary to enunciate that through purposive sampling technique, the data were collected from 240 tomato cultivators of Cumilla and Rangpur districts. The essentials of tomato's production include human labour, fertilizer, bamboo stick, thread, seed/seedlings, ploughing, irrigation, insecticides/pesticides, hormone, etc. It is also indispensable to count the transport costs here. The mentioned factors were collectively considered to estimate the cost of production of tomato. All the data were analyzed statistically and economically while their results have been substantiated through consecutive tables. Farmers are facing different types of problems and this research highlights this issue. The findings show that the total cost of tomato was higher in Cumilla (Tk. 155,515/acre) than that of Rangpur (Tk. 151,224/acre). Gross returns from tomato in Cumilla and Rangpur were Tk. 234,942/acre and Tk. 212,213/acre respectively. The net returns were found higher in Cumilla (Tk. 77,010/acre) than that of Rangpur (Tk. 60,989/acre). Undiscounted benefit cost ratio of tomato production per acre was found to be 1.51 and 1.40 on the basis of total cost for Cumilla and Rangpur districts respectively. The high price of input, lack of storage facilities, price fluctuation, insect and disease damage were the most salient constraints in producing tomato. Up-to-date policy and well-organized extension services have, therefore, to be ensured to augment the income as well as the employment opportunities of the tomato growers.
\end{abstract}

Keywords: Economic Analysis, Tomato Production, Benefit Cost Ratio (BCR), Bangladesh

\section{Introduction}

Agriculture is one of the important sectors pertaining to the economy of Bangladesh where the contribution of agriculture to the GDP is 15 percent while it offers the room of employment for 43 percent of the labor force [5]. Bangladesh is also the most populous country in the world with 156.8 million population [7] with high population density of 1063 person per sq. km. of which 66 percent lives in rural areas [5]. Bangladesh is one of the developing countries where population is growing more rapidly than their food production. Consequently, these countries are combating with the problem of protein and calorie deficiency which inevitably results in malnutrition. Unless our ever-growing population is provided with more food containing protein and vitamin at a low cost, malnutrition cannot be driven out. Here we would like to mention that even the advanced countries cannot deny the importance of agro-sector for supplying their people with protein and vitamin. For example, animal protein and milk product are available in abundance throughout America. It is being increasingly realized that enhancing vegetable production would ensure the fulfilment of the objective of household food, nutritional and economic security in a single go.

Vegetables sub-sector plays an important role for the development of Bangladesh. Vegetables are a herbaceous plant whose fruits, seeds, roots, tubers, leaves etc., are used as food. Vegetables can be counted as a cheaper but most indispensable nutritional source. Here it would be mentioned that vegetables can be grown in a small area of land, even in the homestead or in the rooftops. Another advantage of 
vegetable cultivation is that wide variety of vegetables can be produced all the year round across the country. In addition, vegetable sector is labor intensive and it offers the county a substantial and wide avenue for generating rural employment opportunities extensively. Our fertile land offers our countrymen to grow various kinds of vegetables in a huge quantity round the year but winter climate is most suitable for growing vegetables. A good number of studies [1-3, 8, 12-14] were also being conducted and those studies are related to costs and returns of different vegetables including tomato. Previous researches were highlighted the profitability of tomato production and find out the major problems of tomato production in different areas of Bangladesh. The present study has emphasized not only the costs and returns of tomato production but also established the relationship between socioeconomic characteristics and problems faced by the tomato farmers. This study carefully investigates the major problems of tomato farmers in the selected districts. The findings of the research will be helpful to the policy maker to formulate an effective guideline for the tomato cultivators' days ahead.

\subsection{Production of Tomato}

Tomato is one of the salient food items not only in Bangladesh but also in every country of the globe. Tomato production in Bangladesh is mainly a smallholder activity to provide income to the farming community and all others who are involved in its production and marketing. Tomato farming requires seed, land, labour, capital and fertilizers. The use of primitive technique is held responsible for the low production of tomato. Hence, the production of tomato demands an upto-date management system. We have to bear in mind that tomato production is vulnerable to bad weather particularly rain which may result in huge damage of crop.

Tomato is mainly winter crop. But with the thrivement of the agro-sector, now-a-days, like many other crops, tomato is being grown more or less all the year round. Hence, the production as well as the use of tomato is on the increase across the country. Table 1 shows the Area and Production of tomato in Cumilla and Rangpur districts from 2014-15 to 2018-19.

Table 1. Areas and Production of Tomato from 2014-15 to 2018-19 (Area in acres and production in metric tons).

\begin{tabular}{lllllllllll}
\hline Name of the & $\mathbf{2 0 1 4 - 1 5}$ & \multicolumn{3}{c}{$\mathbf{2 0 1 5 - 1 6}$} & 2016-17 & 2017-18 & \multicolumn{2}{c}{ 2018-19 } \\
\cline { 2 - 10 } District & Area & Production & Area & Production & Area & Production & Area & Production & Area & Production \\
\hline Cumilla & 3984 & 27899 & 4248 & 29086 & 3541 & 27028 & 3579 & 27045 & 3477 & 27226 \\
Rangpur & 531 & 1255 & 530 & 1272 & 510 & 2604 & 674 & 1991 & 680 & 2762 \\
\hline
\end{tabular}

Source: BBS 2017, BBS 2019

Tomato is grown in winter months of Bangladesh as the temperature is congenial at that period of time for optimum growth and yield. But it has great potentiality to grow in summer also. Because of its palatability and vitamin content, its demand in general is growing day by day. Tomato is one of the essential vegetables for growth and maintenance of health of human beings. In the month of December to March varieties of tomatoes are available throughout Bangladesh. Our population is increasing day by day and so is the demand of tomato be it in domestic consumption or be it in other use. Tomato has a queer variety of uses like vegetables and other food items. It is tomato which makes the food palatable. It has high medicinal values because it contains vitamin C\&A, calcium and iron.

\subsection{Objectives}

1. To ascertain the socio-economic characteristics of tomato producers in the study area.

2. To analyze the profitability of tomato production.

3 . To ascertain the problems of tomato cultivation.

4. To put forward policy implications for improvement of tomato production in Bangladesh.

\section{Methodology}

The present study was conducted at Cumilla and Rangpur district. These two districts were chosen purposively as the study area because they are renowned for tomato production in Bangladesh. The farmers in the study area usually produce high yielding variety of tomato and then they are to depend on the middlemen to sell their product. Data for the study were collected during the month of January'2019 to April' 2019. A random sampling technique was applied for selecting sample. Through random sampling 240 farmers were selected for the study. Among them, 120 farmers were from Cumilla and 120 farmers were from Rangpur. The study is involved in collection of data both from the primary and secondary sources. Primary data were collected by the personal interview with the respondents. The secondary sources include govt. publications, annual reports on tomato cultivation, seminar papers, journals, published and unpublished theses, and topic related various books, BBS, web site etc. Tabular and simple statistical methods were used to analyze the collected data. The collected data were analyzed as per objective of the study. The following formulas were used to estimate cost and return for different vegetables:

Total variable cost $=$ Labor cost + Ploughing cost + Chemical fertilizer cost + Manure Cost + Seed and seedling cost + Irrigation cost + Pesticide and insecticide cost + Bamboo Stick and thread cost + Hormone cost + Transportation cost. 
Gross Margin= Total return - Total variable cost

Net Return $=$ Total return- Total cost

Benefit cost ratio (Total cost basis) $=$ Gross return/Total cost

\section{Results and Discussion}

\subsection{Socio-Economic Characteristics of Tomato Farmers}

Socio-economic changes and overall modernization of agriculture on the farms of the farmers are governed by various personal, socio-economical and environmental factors. Farmers' profiles viz., age of the farmer, educational level, income of the farmers, farming experience, family size and farm size etc. affect the knowledge and production efficiency of the farmers. Table 2 shows the socio-economic feature of the sample farmers.
Farmer's average age was 40.27 years with a standard deviation of 11.34 and 39 years with a standard deviation of 11.20 for Cumilla and Rangpur respectively. Farmer's average year of schooling was 6.87 with a standard deviation of 2.95 and 6.01 years with a standard deviation of 4.08 for Cumilla and Rangpur respectively. Farmer's average total family member was 5 in the study area. Average farm size was 0.67 acres and 0.89 acres in Cumilla and Rangpur respectively. Average farming experience was higher in Cumilla (12.35 years). Average annual income of the farmers was Tk.195,189 and Tk.121,813 for Cumilla and Rangpur districts respectively.

Table 2. Socio economic characteristics of tomato farmers.

\begin{tabular}{|c|c|c|c|c|c|c|c|}
\hline District & Sample Size & Age & Education Level & Family Size & Farm Size & Farming Experience & Income of the farmers \\
\hline Cumilla & 120 & $40.27(11.34)$ & $6.87(2.95)$ & $5.17(2.01)$ & $0.67(0.167)$ & $12.35(5.83)$ & 195189 (146397) \\
\hline Rangpur & 120 & $39.00(11.20)$ & $6.01(4.08)$ & $5.14(2.03)$ & $0.89(1.07)$ & $9.89(5.18)$ & $121813(44931)$ \\
\hline
\end{tabular}

Source: Field survey, 2019

\subsection{Costs of the Tomato Cultivation in the Study Area}

For calculating the cost of cultivation of tomato, all variable costs like human labour, land preparation, seed, manures, fertilizers, pesticide, hormone, irrigation, bamboo stick and thread costs were calculated on a per acre basis. The fixed cost of tomato cultivation included cost of land use and interest on operating capital. The total cost includes fixed cost and variable cost. The total cost of production of tomato was Tk.155,515/acre and Tk. 151,224/acre for Cumilla and
Rangpur districts. Total variable cost for Cumilla and Rangpur was Tk 121,157/acre and Tk. 123,463/acre respectively. Total fixed cost was Tk.34,359 and Tk. 27,761 per acre for Cumilla and Rangpur respectively (Table 3). The major component of the cost was labor $(27.13 \%$ and $25.67 \%$ ), chemical fertilizers (16.56\% and $18.00 \%$ ), bamboo stick and thread costs $(15.09 \%$ and $15.72 \%)$ of the total costs of cultivation for Cumilla and Rangpur respectively.

Table 3. Per acre costs of different inputs used in tomato production (Tk.) in Cumilla and Rangpur district.

\begin{tabular}{lllll}
\hline \multirow{2}{*}{ Parameters } & Cumilla & & Rangpur & Percentage of cost \\
\cline { 2 - 5 } & Amount & Percentage of cost & Amount & 25.67 \\
\hline Labor & 42,195 & 27.13 & 38,813 & 14.68 \\
Family & 22,195 & 14.27 & 22,200 & 10.99 \\
Hired & 20,000 & 12.86 & 16,613 & 2.90 \\
Ploughing & 3,238 & 2.08 & 4,3867 & 18.00 \\
Chemical Fertilizer & 25,750 & 16.56 & 27,217 & 2.27 \\
Manure & 3,333 & 2.14 & 3,433 & 5.41 \\
Seed/Seedling & 7,627 & 4.90 & 2.64 \\
Irrigation & 3,496 & 2.25 & 3,992 & 3.57 \\
Pesticides/Insecticides & 5,031 & 3.23 & 5,395 & 15.72 \\
Bamboo Stick and thread & 23,467 & 15.09 & 23,775 & 2.30 \\
Hormone & 4,211 & 2.71 & 3,474 & 3.17 \\
Transportation & 2,810 & 1.81 & 4,794 & 81.64 \\
Total variable cost (Tk/acre) & 121,157 & 77.91 & 123,463 & 17.19 \\
Land value (for 4months) & 33,333 & 21.43 & 26,000 & 1.16 \\
Interest (for 4months) & 1,026 & 0.66 & 1,761 & 18.36 \\
Total Fixed cost (Tk/acre) & 34,359 & 22.09 & 27,761 & 100.00 \\
Total cost (Tk/acre) & 155,515 & 100.00 & 151,224 & \\
\hline
\end{tabular}

Source: Field survey, 2019 


\subsection{Profitability of Tomato Cultivation}

Table 4 indicates the average gross return, gross margin and net return of tomato for Cumilla and Rangpur districts. On an average yield for Cumilla was $18,795.33 \mathrm{~kg} / \mathrm{acre}$ and for Rangpur was $18,453.33 \mathrm{~kg} / \mathrm{acre}$. Gross return per acre were Tk. 234,942 and Tk. 212,213 in Cumilla and Rangpur respectively. Gross margin per acre were Tk.111,368 and Tk. 88,750 for Cumilla and Rangpur respectively. Between the two districts, net return per acre was high in Cumilla (Tk. 77,010) than that of Rangpur (Tk. 60,989). Two main reasons may be the cause of higher net return in Cumilla. One is the total variable cost which was lower in Cumilla and the second reason is farmer get the highest price for tomato in Cumilla than Rangpur district. BCR based on the total cost was 1.51 and 1.40 for Cumilla and Rangpur respectively. BCR was greater than one in the study area indicating that growing of tomato is a profitable. The findings of the study have revealed that overall farmers of the study area are getting good profits from tomato production.

\subsection{Constraints to Tomato Production}

Tomato cultivation is no doubt, potentially profitable but it is found that there are a good number of hurdles to the way of its desirable production. Table 5 revealed that, high price of input, lack of storage facilities, price fluctuation, insect and disease damage are the most obvious constraints of producing tomato. Moreover, non-availability of seed on time, lack of capital and lack of government support are also reported as major problems faced by the tomato farmers in the study area.

Table 4. Per acre profitability of producing tomato in Cumilla and Rangpur district.

\begin{tabular}{lll}
\hline Parameters & Cumilla & Rangpur \\
\hline Average Yield (Kg.) & 18795.33 & 18453.33 \\
Price (Tk./kg.) & 12.50 & 11.50 \\
Gross return (Tk./acre) & 234941.67 & 212213.33 \\
Gross costs (Tk.) & 155515.43 & 151224.00 \\
Gross margin (Tk./acre) & 111368.23 & 88750.00 \\
Net return (Tk./acre) & 77009.57 & 60989.33 \\
Benefit cost ratio (Total cost basis) & 1.51 & 1.40 \\
\hline
\end{tabular}

Source: Field survey, 2019

Table 5. Problems faced by the tomato farmers.

\begin{tabular}{|c|c|c|c|c|}
\hline \multirow{2}{*}{ Problems } & \multicolumn{2}{|l|}{ Cumilla } & \multicolumn{2}{|l|}{ Rangpur } \\
\hline & Number of respondents $(\mathrm{N}=120)$ & Percent & Number of respondents $(\mathrm{N}=120)$ & Percent \\
\hline High price of input & 50 & 41.67 & 55 & 45.83 \\
\hline Non-availability of seed in time & 24 & 20.00 & 30 & 25.00 \\
\hline Lack of storage facilities & 50 & 41.67 & 60 & 50.00 \\
\hline Insect and disease damage & 36 & 30.00 & 37 & 30.83 \\
\hline Price fluctuation & 42 & 35.00 & 45 & 37.50 \\
\hline Lack of Capital & 16 & 13.33 & 18 & 15.00 \\
\hline
\end{tabular}

Source: Field survey, 2019

\section{Conclusions and Policy Recommendations}

The profitability and prospect of tomato production along with farmers' problems have been pin-pointedly examined in this paper. It is palpably found that tomato production is highly profitable in the study area. But many problems like high price of input, lack of storage facilities, price fluctuation, insect and disease damage, unavailability of seed in time, paucity of capital, dearth of government support are reported as major obstacles standing on the way of growing tomato in the study area. It is, therefore, recommended that input availability, storage facilities, effective policy and efficient extension services have to be ensured to increase income and employment opportunities of the tomato farmers. Moreover, it is necessary to extend the monitoring and support of the government for promoting the development of vegetable products. Crown it to all, if modern inputs and production technologies had been available in time, the yield and production of tomato would have soared and so would the financial status of our tomato farmers. Optimistically speaking, if the adversities or problems faced our farmers in general and tomato farmers in particular are dissolved, a large number of people will be prone to coming to grow tomato which will not only supply us with required vitamins and calories but also contribute a lot to our national economy.

\section{References}

[1] Ahmed, J. U. 2001. A comparative economic study of potato and cauliflower production in a selected area of Cumilla district. M. S. Thesis, Department of Agricultural Economics, BAU, Mymensingh, Bangladesh.

[2] Akhter, F. 2006. Economics of some selected winter vegetables production in an area of Trishal upazila in Mymensingh district. M. S. Thesis, Department of Agricultural Economics, BAU, Mymensingh, Bangladesh.

[3] Awal M A. 2013. An economic analysis of potato and carrot production in selected areas of Mymensingh district. M. S. Thesis, Department of Agricultural Economics, Bangladesh Agricultural University, Mymensingh.

[4] BBS 2019. Statistical Yearbook of Bangladesh,, Statistics Division, Ministry of Planning, Government of the People's Republic of Bangladesh, Dhaka. 
[5] BBS 2018. Statistical Yearbook of Bangladesh, Bangladesh Bureau of Statistics, Statistics and Informatics Division (SID) Ministry of Planning.

[6] BBS 2017. Statistical Yearbook of Bangladesh,, Statistics Division, Ministry of Planning, Government of the People's Republic of Bangladesh, Dhaka.

[7] BBS 2014. Statistical Yearbook of Bangladesh, Bangladesh Bureau of Statistics, Statistics.

[8] Chowdhury S (1996). Growth and Instability of Area and Production of Some Selected Winter Crops in Bangladesh. M.S. Thesis, Department of Agricultural Economics, BAU, Mymensingh, Bangladesh.

[9] Hajong, Pradip \& Sikder, B \& Mondal, Shimul \& Islam, Md (2018). Adoption and profitability of summer tomato cultivation in Jashore district of Bangladesh. Bangladesh Journal of Agricultural Research. 43. 575. 10.3329/bjar.v43i4.39154.

[10] Hasan, Md \& Bai, H. (2016). PROFITABILITY OF TOMATO PRODUCTION IN THREE DISTRICTS OF BANGLADESH. 1-8.
[11] Hossain, M. M. 1997. A comparative economic analysis of some selected high yielding varieties of winter vegetables in an area of Bangladesh. M. S. Thesis, Department of Agricultural Economics, BAU, Mymensingh, Bangladesh.

[12] Karim, M. R., M. S. Rahman and M. S. Alam. 2009. Profitability of summer BARI Hybrid tomato cultivation in Jessore district of Bangladesh, J Agric Rural Dev 7 (1 \& 2), pp. 73-79.

[13] Mowla, M. G. 1998. An economic Analysis of Some Selected Winter Vegetables in a Selected Area of Narsingdi District, M. S. Thesis, Department of Agricultural Economics, BAU, Mymensingh, Bangladesh.

[14] Naher, S. 1998. An Economic Analysis of Vegetables Production in a Selected Area of Mymensingh District. M. S. Thesis, Department of Agricultural Economics, BAU, Mymensingh, Bangladesh.

[15] Sultana, M. S. 2001. Economic Study on Commercially Produced Winter Vegetables in Some selected Areas of Comilla District, M. S. Thesis, Department of Agricultural Economics, BAU, Mymensingh, Bangladesh. 